\title{
Decision Support System Untuk Menetapkan Daya Listrik Bagi Pelanggan PLN
}

\author{
Sifa Fauziah', Sri Muryani \\ ${ }^{1}$ Universitas Bina Sarana Informatika \\ e-mail: sifa.saz@bsi.ac.id \\ ${ }^{2}$ STMIK Nusa Mandiri \\ e-mail: sri.smy@nusamandiri.ac.id
}

\begin{abstract}
The need for electrical energy is very dominant for humans, starting from the needs in the household, government business, home industry to large industries and all other aspects of life, now means that the availability of electricity is very important and very influential in increasing the socio-economic quality growth rate society in general. A PLN user to find out how much lamp power is needed in a room judging subjectively that is still in accordance with his own wishes. This writing makes the application using fuzzy logic to find out how much electrical power is used in an appropriate manner. To make it easier for a PLN user to determine the electrical power that is in accordance with the requirements, the author makes the application using fuzzy logic. The programming language used is visual basic. The benefit of this writing is to help a PLN user to optimize electric power so that it can save energy.
\end{abstract}

Key Word: Fuzzy Logic, Determining Electric

\section{PENDAHULUAN}

Energi Listrik merupakan kebutuhan primer bagi seluruh lapisan masyarakat, Energi Listrik mempunyai banyak manfaat dalam kehidupan sehari -hari baik di sector rumah tangga, transportasi maupun industri (Oxa \& Erma, 2012).

PT Perusahaan Listrik Negara atau biasa disebut PT. PLN adalah Badan Usaha Milik Negara yang masih menyediakan subsidi tarif tenaga listrik untuk rumah tangga (Widarma \& Kumala, 2018).

Ketersediaan listrik merupakan bagian yang tidak terpisahkan bagi kehidupan saat ini. Kebutuhan energi listrik sangat dominan bagi manusia, dimulai dari kebutuhan didalam rumah tangga, bisnis pemerintahan, industri rumah tangga hingga industri besar serta seluruh aspek kehidupan lainnya, sehingga ketersediaan energi listrik saat ini sangat penting dan sangat berpengaruh dalam meningkatkan laju pertumbuhan kualitas sosial ekonomi masyarakat secara umum.

Prakiraan kebutuhan tenaga listrik dipengaruhi salah satunya dipengaruhi oleh sistem pencahayaan yang tepat dalam suatu ruangan. Besarnya daya listrik yang digunakan yang berkaitan dengan kebijakan pemerintah, tingkat perekonomian dan jumlah penduduk serta jumlah rumah tangga. Semakin tinggi tingkat perekonomian akan menyebabkan aktivitas penggunaan tenaga listriknya semakin tinggi, begitu juga untuk jumlah penduduk (Indriani \& Supriyono, 2007).

Untuk mengatasi permasalahan di atas, maka penulis menggunakan logika fuzzy dalam penentuan efektifitas penggunaan kapasitas daya listrik bagi pelanggan dan membangun suatu sistem pengambilan keputusan yang optimal dalam menentukan daya listrik pada pelanggan.

Untuk mengatasi permasalahan di atas, maka penulis menggunakan logika fuzzy dan perangkat lunak Microsoft Visual Basic dalam penentuan efektifitas penggunaan listrik, serta mendukung keputusan bagi seorang pengguna PLN untuk menentukan berapa beban daya listrik yang tepat dan yang sesuai dengan kebutuhan dan membangun suatu sistem pengambilan keputusan yang optimal dalam menentukan daya listrik.

\section{Sistem Penunjang Keputusan}

Definisi SPK secara sederhana adalah sebuah sistem yang digunakan sebagai alat bantu menyelesaikan masalah untuk membantu pengambil keputusan (manajer) dalam menentukan keputusan tetapi tidak untuk menggantikan kapasitas manajer hanya memberikan pertimbangan (Ishak, 2017).

Sistem pendukung keputusan (SPK) atau Decision Support System (DSS) adalah sistem informasi interaktif yang menyediakan informasi, pemodelan, dan pemanipulasian data yang digunakan untuk membantu pengambilan keputusan pada situasi yang semiterstruktur dan situasi yang tidak terstruktur dimana tidak seorang pun tahu secara pasti bagaimana keputusan seharusnya dibuat (Kadir, 2013).

\section{Listrik}

Teknik Instalasi listrik pada rumah tinggal adalah suatu sistem/rangkaian yang digunakan untuk menyalurkan daya listrik ke lampu atau alat-alat listrik yang lain sebagai penunjang aktifitas rumah tangga sehari-harI (Kautsar, Marzuki, \& Sadrina, 2018). 


\section{Logika Fuzzy}

Logika fuzzy adalah suatu cara untuk memetakan suatu ruang masukan ke dalam suatu ruang keluaran. Dalam teori logika fuzzy dikenal himpunan fuzzy (fuzzy set) (Laksono \& Effendi, 2011).

Logika fuzzy berbeda dengan logika digital biasa, dimana logika digital biasa hanya mengenal dua keadaan yaitu: Ya dan Tidak atau ON dan OFF atau High dan Low atau "1" dan "0". Sedangkan Logika Fuzzy meniru cara berpikir manusia dengan menggunakan konsep sifat kesamaran suatu nilai. Dengan teori himpunan fuzzy, suatu objek dapat menjadi anggota dari banyak himpunan dengan derajat keanggotaan yang berbeda dalam masingmasing himpunan (Wulandari, 2005)

\section{METODOLOGI PENELITIAN}

Sesuai dengan kebutuhan dalam penelitian ini langkah-langkah penelitiannya sebagai berikut:

\section{a. Analisis Data}

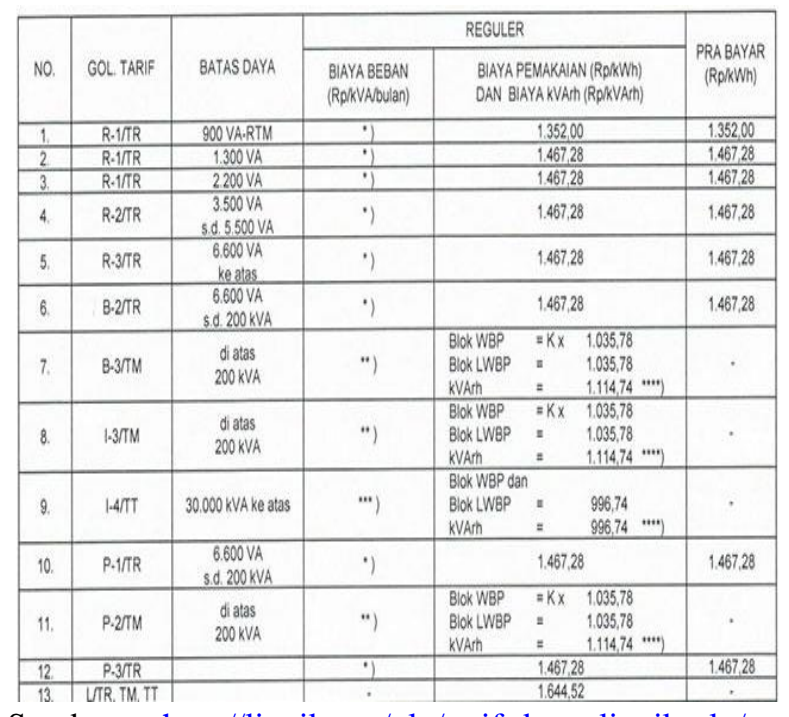

Sumber: http://listrik.org/pln/tarif-dasar-listrik-pln/ (2018)

Gambar 1. Tarif Dasar Listrik.

Tarif dasar listrik adalah tarif harga jual listrik yang dikenakan pemerintah untuk para pelanggan PLN. Tarif dasar listrik bisa disebut juga tarif tenaga listrik. PLN memiliki tarif subsidi dan non-subsidi.

Gambar 1 diatas diasumsikan secara umum pemakaian listrik yang dengan menetapkan batas daya per golongan tarif. Batas daya yang ada dijadikan acuan bagi pelanggan yang ingin memasang listrik baru dan perubahan daya. Penetapan daya juga berdasarkan pada golongan tarif pemakai listrik.

\section{Tarif Dasar Listrik Rumah Tangga R1}

\begin{tabular}{|l|l|l|}
\hline Golongan Tarif/Daya & Keterangan & Tarif (Rp / $\mathbf{k W h})$ \\
\hline R-1/450 VA & Subsidi & 415 \\
\hline R-1/900 VA & Subsidi & 586 \\
\hline R-1/900 VA-RTM (Rumah Tangga Mampu) & Non-Subsidi & 1352 \\
\hline R-1/1300 VA & Non-Subsidi & 1467,28 \\
\hline R-1/2200 VA & Non-Subsidi & 1467,28 \\
\hline R-2/3500 VA, 4400 VA, 5500 VA & Non-Subsidi & 1467,28 \\
\hline R-3/6600 VA ke atas & Non-Subsidi & 1467,28 \\
\hline
\end{tabular}

Sumber: http://listrik.org/pln/tarif-dasar-listrik-pln/ (2018)

Gambar 2. Tarif Dasar Listrik Rumah Tangga R1

Berdasarkan gambar 2 terlihat pembagian tarif dasar listrik untuk rumah tangga, beserta penjelasan yang subsidi dan non-subsidi.

Pada dasarnya, penentuan daya ditentukan sendiri oleh pelanggan yang bersangkutan sesuai dengan keinginan mereka sendiri, Sehingga tidak ada faktor yang mendukung keputusan pelanggan dalam menetapkan daya.

Disamping itu tidak adanya aplikasi yang membantu pelanggan yang mengukur kapasitas daya yang sesuai dengan mereka, Maka rentangan daya yang ada itulah menjadi pilihan bagi pelanggan.

Didalam analisa sistem ini, dilakukan identifikasi terhadap keterkaitan antara elemen elemen yang menjadi faktor penetapan daya pelanggan.

Untuk lebih jelas, saya membagi penelitian ini pada dua buah sistem pelayanan pelanggan PLN sebagai acuan merancang sistem penunjang keputusan dalam penetapan daya pelanggan, yaitu :

1. Proses pemasangan baru pelanggan.

Menggambarkan secara umum proses bisnisnya mulai dari registrasi pelanggan sampai pengentrian pelanggan baru. Disini juga terdapat hasil survei yang dilakukan oleh petugas PLN mengindikasikan bahwa ada atau tidaknya jaringan listrik disekitar pemasangan baru.

2. Proses perubahan daya.

Terdiri dari penambahan dan penurunan daya. pada perubahan daya, pelanggan yang ingin melakukan transaksi perubahan akan memberikan rekening terakhir dan mengisi surat permohonan perubahan daya untuk diproses dalam entri perubahan daya.

\section{b. Menentukan Model DSS}

Model yang cocok digunakan untuk merancang SPK ini adalah model statistik. Dengan mensimulasikan faktor-faktor pendukung yang menentukan daya listrik, sehingga akan dapat menghitung jumlah daya yang ideal.

Untuk dapat membuat sebuah model statistik, penulis mengambil sebuah sampel yang sederhana 
dari kasus ini berdasarkan alat listrik yang ada pada pelanggan. memiliki :

Diasumsikan bahwa suatu rumah tangga

a. 5 lampu hemat energy (LHE) $20 \mathrm{~W}$

b. 2 buah Lemari ES $50 \mathrm{~W}$

c. Setrika $300 \mathrm{~W}$

Dengan alat-alat ini, maka akan dicari jumlah daya yang cocok dalam Rentangan daya yang ada antara lain:

Tabel 2. Batas Daya Berdasarkan Golongan Tarif

\begin{tabular}{cc}
\hline Golongan Tarif & Batas Daya \\
\hline R-1/TR & 900 \\
\hline R-1/TR & 1300 \\
\hline R-1/TR & 2200 \\
\hline
\end{tabular}

Menghitung Kapasitas Daya dengan rumus (Erdisna, 2012):

Daya alat listrik $($ Watt $)=$ Daya pada PLN $($ VA $) * 0,8$

Maka : Daya $($ VA $)=$ Daya aktif $/ 0,8$

$$
\begin{aligned}
\text { Daya lampu }= & (5 \times 20 \mathrm{~W}) / 0,8 \\
& =100 \mathrm{~W} / 0,8 \\
& =125 \mathrm{VA}
\end{aligned}
$$

$$
\begin{aligned}
\text { Daya Lemari Es } & =(50 \mathrm{~W} \times 2) / 0,8 \\
& =100 \mathrm{~W} / 0,8 \\
& =125 \mathrm{VA}
\end{aligned}
$$

Daya Setrika $=300 \mathrm{~W} / 0,8$

$$
=475 \mathrm{VA}
$$

Dapat kita lihat bahwa Total daya dari jumlah alat listrik yang ada adalah 725 VA, Dimana 725 VA mendekati daya 900 VA. Jadi dapat disarankan pelanggan tersebut memilih daya $900 \mathrm{VA}$.

Tabel 3 : Rentangan daya PLN

\begin{tabular}{cc}
\hline Golongan Tarif & Batas Daya (VA) \\
\hline R-1/TR & 900 \\
\hline R-1/TR & 1300 \\
\hline R-1/TR & 2200 \\
\hline
\end{tabular}

Sumber: Hasil Penelitian (2018)

\section{c. Pembuatan perancangan sistem}

Dalam penelitian ini telah dilaksanakan metode perancangan, yaitu perancangan fungsi-fungsi keanggotaan, perancangan aturan fuzzy, perancangan prosedur dan perancangan tampilan (antar muka).

\section{d. Membangun program komputer}

Program komputer yang digunakan untuk membangun sistem ini adalah perangkat lunak Microsoft Visual Basic 6.0 dengan alasan bahwa Microsoft Visual Basic 6.0 merupakan bahasa komputasi teknis yang sangat populer dan sangat mudah digunakan serta mudah pula untuk dipahami struktur bahasanya.

\section{HASIL DAN PEMBAHASAN}

\subsection{Rancangan Database}

Untuk merancang database penulis menggunakan SQL. Dengan Nama databasenya adalah daya_listrik.

Struktur database yang dirancang dalam penulisan ini terdiri dari tabel pelanggan, tabel pasang_baru, dan tabel perubahan_daya.

\subsection{Perancangan Model}

Dalam memecahkan masalah, diperlukan sebuah model untuk dapat memudahkan pekerjaan dalam membangun sistem penunjang keputusan. Perancangan model ini terdiri dari objek-objek yang saling terkait untuk penetapan daya pelanggan. Untuk dapat membedakannya, kita lihat beberapa objek tersebut:

\section{Variabel keputusan}

Variabel yang dibutuhkan dalam mengambil keputusan dalam kasus ini, adalah sebagai berikut:
a. Kapasitas peralatan listrik yang ada pelanggan.
b. Golongan pengguna listrik.
c. Luas area

\section{Fungsi tujuan}

Tujuan pembangunan DSS ini bagi pelanggan adalah :

a. Mengetahui jumlah daya listrik yang cocok dan akurat untuk mereka.

b. Dapat menghemat penggunaan energi listrik.

c. Mengurangi biaya pengeluaran bulanan pelanggan.

Sedangkan bagi PLN adalah:
a. Menghindari pemborosan pasokan listrik kepelanggan.
b. Mengurangi beban daya yang besar.

\section{Batasan Model.}

Pada Kasus ini terdapat sub masalah dalam menentukan daya pelanggan yaitu proses instalasi baru dan perubahan daya.

1. Batasan untuk proses pemasangan baru.

Menghitung perkiraan daya pada proses Memasangan baru memerlukan aspek-aspek diantaranya :
a. Peralatan listrik yang ada pada pelanggan.
b. Golongan pemakai
c. Luas area

2. Batasan untuk proses perubahan daya.

Dalam mengitung daya listrik untuk proses perubahan daya, variabel yang dibutuhkan adalah: 

a. Jumlah alat-alat listrik yang ada
b. Luas area
c. Golongan pemakai

\subsection{Pemecahan Model}

Sesuai dengan pokok bahasan bahwa hasil dari penelitian ini adalah menentukan daya yang cocok untuk pelanggan dengan mengacu pada aspek yang menetukan daya bagi pelanggan tersebut.

Sistem penunjang keputusan dirancang sedemikian rupa, sehingga pengguna dalam hal ini adalah manajer bisa menentukan penilaian sendiri secara dinamis untuk menetukan daya pelanggan.

Dalam kasus ini aspek - aspek yang digunakan adalah :

1. Jumlah alat - alat listrik yang digunakan.

Faktor alat listrik sangatlah penting untuk dijadikan acuan dalam penetapan daya pelanggan . aspek ini terdiri dari variabel - variabel yaitu :

a. Jenis alat listrik

b. Jumlah

c. Kapasitas daya alat listrik tersebut (Watt)

2. Luas area bangunan.

Besar kecil luas bangunan mempengaruhi perhitungan daya pelanggan.

3. Golongan pemakai listrik.

Energi (volt) yang ada pada alat listrik mempengaruhi penilaian untuk menentukan daya.

\subsection{Pembahasan}

Tujuan akhir perancangan model ini adalah melakukan simulasi perhitungan penentuan daya dengan mempertimbangkan variabel variabel keputusan untuk mendapatkan daya yang ideal bagi pelanggan. Untuk lebih jelas dapat diambil sampel dari data pelanggan PLN.

Tabel 4. Sampel Data Pelangan PLN

\begin{tabular}{cccccc}
\hline $\begin{array}{c}\text { No } \\
\mathbf{1}\end{array}$ & Id Pelanggan & $\begin{array}{c}\text { Nama } \\
\text { Pelanggan }\end{array}$ & $\begin{array}{c}\text { Golonga } \\
\text { n Tarif }\end{array}$ & $\begin{array}{c}\text { Day } \\
\mathbf{a}\end{array}$ & $\begin{array}{c}\text { Keperlua } \\
\mathbf{n}\end{array}$ \\
\hline $\mathbf{1}$ & $\begin{array}{c}13200033015 \\
8\end{array}$ & Sandy & R1 & 900 & $\begin{array}{c}\text { Rumah } \\
\text { Tangga }\end{array}$ \\
\hline $\mathbf{2}$ & $\begin{array}{c}13200033041 \\
0\end{array}$ & $\begin{array}{c}\text { Rina } \\
\text { Mutiara } \\
\text { Sari }\end{array}$ & R1 & 1300 & $\begin{array}{c}\text { Rumah } \\
\text { Tangga }\end{array}$ \\
\hline $\mathbf{3}$ & $\begin{array}{c}13200033042 \\
8\end{array}$ & $\begin{array}{c}\text { Muhamma } \\
\text { d Ridwan }\end{array}$ & B1 & 2200 & Bisnis \\
\hline $\mathbf{4}$ & $\begin{array}{c}13200033262 \\
2\end{array}$ & Nova Dwi & B1 & 900 & Bisnis \\
\hline $\mathbf{5}$ & 13203305325 & $\begin{array}{c}\text { Yanti } \\
4\end{array}$ & S1 & 900 & $\begin{array}{c}\text { Badan } \\
\text { Sahy }\end{array}$ \\
\hline Sumial
\end{tabular}

Sumber: Hasil Penelitian (2018)

Menghitung daya alat listrik yang ada dengan menggunakan rumus (Erdisna, 2012):

$$
\text { Daya }(\text { VA })=\text { Watt } / 0,8
$$

Tabel 5. Hasil Perhitungan Daya Listrik untuk ID Pelanggan

\begin{tabular}{|c|c|c|c|c|}
\hline No & $\begin{array}{c}\text { Alat } \\
\text { Listrik }\end{array}$ & $\begin{array}{c}\text { Jumlah } \\
\text { Item }\end{array}$ & Daya & Total Daya \\
\hline 1 & Lampu & 30 & 18 & $30 \times 18 / 0,8=675$ \\
\hline 2 & $\mathrm{AC}$ & 10 & 50 & $10 \times 500 / 0,8=625$ \\
\hline 3 & Komputer & 15 & 80 & $15 \times 80 / 0,8=1500$ \\
\hline 4 & Dispenser & 2 & 100 & $30 \times 18 / 0,8=675$ \\
\hline \multicolumn{4}{|c|}{ Total } & 2925 \\
\hline
\end{tabular}

Sumber: Hasil Penelitian (2018)

Dengan melakukan perhitungan berdasarkan faktor alat-alat listrik diatas, maka pelanggan tersebut disarankan untuk memilih daya yang mendekati dengan total daya alat listrik yang ada. Penetapan daya ini bertujuan agar tidak terbebani dengan jumlah alat listrik yang sangat banyak. Namun Perhitungan ini belum merupakan hasil yang sesungguhnya, ada beberapa faktor lain yang akan dijelaskan selanjutnya.

1. Membandingkan daya alat listrik dengan luas area bangunan kantor.

Pemilihan daya juga berdasarkan pada luas area perkantoran. Faktor ini mencakup faktor alat-alat listrik yang akan digunakan. Berdasarkan faktor alat listrik diatas, daya yang didapat adalah 2925 VA terletak antara rentangan daya 2200- 3500 VA. Jika dibandingkan dengan luas area kantor yang besarnya $500 \mathrm{M}^{2}$, maka disarankan pada perusahaan tersebut cukup untuk memilih daya ke arah bawah rentangan daya dari perhitungan alat listrik. Hal ini disebabkan karena area kantor tersebut tidak terlalu luas dan bertujuan untuk melakukan penghematan pembelian alat listrik. langkah selanjutnya adalah mempertimbangkan ketiga faktor

2. Menggabungkan faktor alat listrik, luas bangunan dan penggunaan listrik.

Dilihat dari kasus diatas, pelanggan tersebut termasuk kedalam pelanggan bisnis, dimana diperkirakan akan menggunakan alat-alat listrik secara bersamaan dan dalam durasi waktu yang lama. Sehingga akan membutuhkan daya yang lebih dari kapasitas alat listrik.

Penyelesaian akhir dari kasus ini adalah menggabungkan ketiga faktor-faktor diatas untuk mendapatkan daya yang sesuai. Dengan mensimulasikan faktor diatas pelanggan dengan Id 132000330428 disarankan untuk memilih daya 3500. Pertimbangan pemilihan ini bertujuan bagi penggunaan listrik yang sesuai dengan kebutuhan pelanggan tersebut. 
Tabel 5. Hasil Penetapan Daya Listik

\begin{tabular}{cccc}
$\begin{array}{c}\text { Daya } \\
\text { listrik }\end{array}$ & $\begin{array}{c}\text { Luas } \\
\text { bangunan }\end{array}$ & Keperluan & $\begin{array}{c}\text { Daya yang } \\
\text { Disarankan }\end{array}$ \\
\hline $\begin{array}{c}2925 \\
\text { VA }\end{array}$ & $500 \mathrm{M}^{2}$ & Bisnis & 3500 \\
\hline
\end{tabular}

Sumber: Hasil Penelitian (2018)

Pada tabel 5 ditampilkan hasil penetapan daya listrik untuk daya listrik 2925 VA, luas bangunan $500 \mathrm{M}^{2}$ untuk kepeeluan bisnis daya yang disarankan adalah 3500 .

\subsection{Desain Aplikasi}

\subsubsection{Tampilan Input Data Pelanggan PLN}

DSS Menentukan Daya Listrik

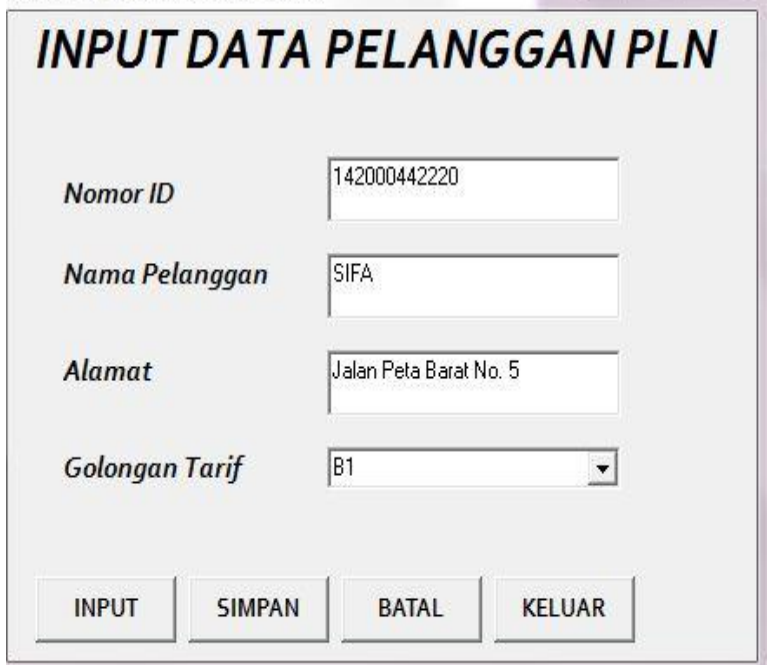

Sumber: Hasil Penelitian (2018)

Gambar 3. Tampilan Input Data Pelanggan PLN

Pada Gambar 2 dapat dilihat form input data pelanggan. Input data pelanggan terdiri dari nomor id, nama pelanggan, alamat dan golongan tarif. Golongan tarif yang bisa dipilih yaitu 900, 1300 atau 2200 .

\subsubsection{Tampilan Menenetapkan Daya Listrik} yang Ideal

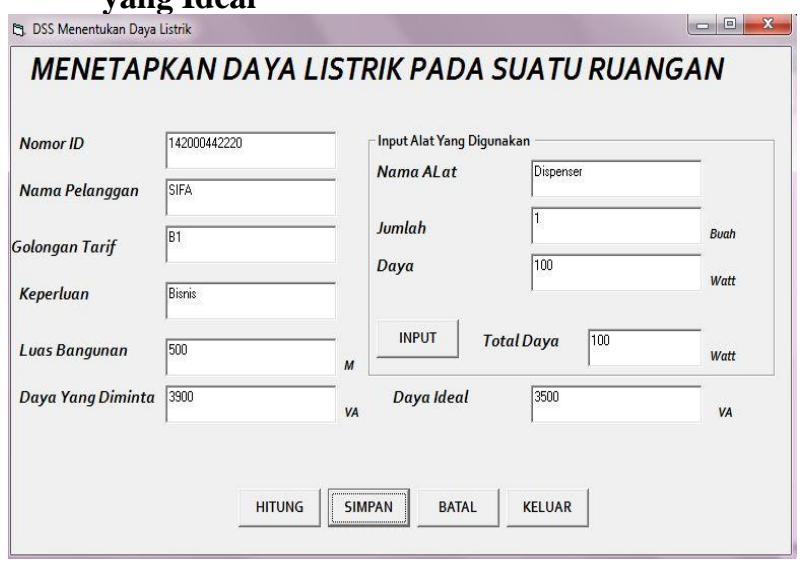

Sumber: Hasil Penelitian (2018)

Gambar 4. Tampilan Menetapkan Daya Listrik
Pada gambar 3 merupakan form menetapkan daya listrik pada suatu ruangan. Form ini berisi data nomor id pelanggan, nama pelanggan, golongan tarif, keperluan, luas bangunan, dan daya yang diminta. Sedangkan keterangan alat terdiri dari nama alat, jumlah, daya, jumlah watt. Di akhri form akan menampilkan daya ideal yang bisa dipilih pelanggan PLN.

\section{KESIMPULAN}

Berdasarkan pembahasan di atas, maka dapat diambil kesimpulan dari penulisan ini adalah:

1. Pada proses menentukan besar daya listrik pada suatu ruangan tertentu membutuhkan tiga faktor utama yaitu kapasitas peralatan listrik yang ada pelanggan, golongan pengguna listrik, dan luas area.

2. Dengan menggunakan sebuah aplikasi berbasis logika fuzzy dapat memudahkan seoarang pengguna PLN dalam menentukan berapa besar daya listrik dalam suatu ruangan menjadi lebih tepat sesuai kebutuhan.

3. Dengan menggunakan algoritma logika fuzzy dapat mengoptimalkan penentuan berapa daya lampu listrik yang dibutuhkan sehingga dapat menciptakan hemat daya listrik.

4. kapasitas peralatan listrik yang dibutuhkan semakin besar, dan luas ruangan semakin luas maka kebutuhan daya listrik semakin lebih besar.

\section{REFERENSI}

Erdisna. (2012). SISTEM PENUNJANG KEPUTUSAN DALAM MENETAPKAN DAYA LISTRIK PELANGGAN PLN. JURNAL TEKNOLOGI INFORMASI \& PENDIDIKAN, 5(2), 121-132.

http://listrik.org/pln/tarif-dasar-listrik-pln/ (2018)

Indriani, F., \& Supriyono. (2007). Membangun Perangkat Lunak Penentuan Daya Listrik Dengan Logika Fuzzy. Seminar Nasional Aplikasi Teknologi Informasi, 2007(Snati), 83-87.

Ishak, R. (2017). Sistem Penunjang Keputusan Penerimaan Karyawan Menggunakan Metode Profile Maching dan Analytical Hierachy Process Pada PT . Sunny Collection. Jurnal Perspektif BSI, XV(2), 136-146.

Kadir, A. (2013). Pengenalan Sistem Informasi. Yogyakarta: Penerbit Andi. 
Kautsar, A., Marzuki, M., \& Sadrina, S. (2018). Pengaruh Penerapan Model Pembelajaran Kooperatif Tipe Jigsaw Terhadap Hasil Belajar Siswa Pada Mata Pelajaran Teknik Instalasi Penerangan Listrik Rumah Sederhana Di SMKN 1 Darul Kamal. CIRCUIT: Jurnal Ilmiah Pendidikan Teknik Elektro, 2(2), 90101. http://doi.org/10.22373/crc.v2i2.3699

Laksono, H. D., \& Effendi, H. (2011). APLIKASI LOGIKA FUZZY PADA PERKIRAAN KEBUTUHAN ENERGI LISTRIK JANGKA PANJANG DI PROVINSI SUMATERA BARAT SAMPAI TAHUN 2018. Jurnal Teknologi Informasi \& Pendidikan, 3(1), 4253.

Oxa, A., \& Erma, S. (2012). Aplikasi Model Sistem Dinamik untuk Menganalisis Permintaan dan Ketersediaan Listrik Sektor Industri (Studi Kasus : Jawa Timur). Jurnal Teknik ITS, 1, A-
339-A-244.

Widarma, A., \& Kumala, H. (2018). Sistem Pendukung Keputusan Dalam Menentukan Pengguna Listrik Subsidi Dan Nonsubsidi Menggunakan Metode Fuzzy Mamdani ( Studi Kasus: PT . PLN Tanjung Balai ). Jurnal Teknologi Informasi), 2(2), 165-171.

Wulandari, F. (2005). Pembuatan Sistem Pendukung Keputusan Berbasis Teori Fuzzy untuk Mengembangkan Suatu Produk Baru. Jurnal Sain, Teknologi \& Industri, 2(2), 62-66.

\section{Biodata Penulis}

Sifa Fauziah, dilahirkan di Jakarta 10 April 1990. Pendidikan terakhir Pascasarjana STMIK Nusa Mandiri Jakarta. Saat ini aktif mengajar di Fakultas Teknologi Informasi Universitas BSI. 